Finanse, Rynki Finansowe, Ubezpieczenia nr 3/2017 (87), cz. 1

\title{
Wybrane aspekty implementacji metodologii Lean w kontekście podniesienia efektywności procesu audytu wewnętrznego w administracji publicznej
}

\begin{abstract}
Anna Bartoszewicz*
Streszczenie: $\mathrm{Cel}$ - Zaprezentowanie zasad funkcjonowania i wybranych narzędzi metodologii Lean Audit oraz wskazanie kluczowych obszarów podnoszenia efektywności procesu audytu.

Metodologia badania - W artykule wykorzystano analizę literatury przedmiotu badań oraz aktów prawnych. Zastosowano metodę obserwacji przebiegu procesu audytu w podmiotach publicznych. Wnioskowanie przeprowadzono metodą indukcji.

Wynik - W artykule zaprezentowano metodologię Lean Audit. Wskazano na możliwość wykorzystania jej narzędzi - SIPOC i modelu MURA w doskonaleniu procesu audytu w administracji publicznej.

Oryginalność/wartość - Zaprezentowana metodologia Lean Audit nie była jak dotąd prezentowana w publikacjach w odniesieniu do polskiej administracji publicznej. Z uwagi na transformację audytu wewnętrznego w sektorze finansów publicznych w Polsce i Nowe Zarządzanie Publiczne ranga tego zagadnienia wzrasta.
\end{abstract}

Słowa kluczowe: audyt, audyt wewnętrzny, Lean Audit, efektywność, SIPOC

\section{Wprowadzenie}

W ostatnich latach, w odpowiedzi na wzrost zainteresowania społeczeństwa poprawą efektywności wydatkowania środków publicznych i ograniczania kosztów przez administrację państwową, wykształcił się nowy model zarządzania publicznego New Public Management. Krokiem w kierunku zmiany koncepcji zarządzania w jednostkach sektora finansów publicznych było adaptowanie rozwiązań, wcześniej wdrożonych w sektorze for-profit. Wskutek podjętych przemian organizacyjnych zaczęto korzystać z takich instrumentów jak budżet zadaniowy, zarządzanie ryzykiem czy kontrola zarządcza. Wsparciem dla Nowoczesnego Zarządzania Publicznego stała się metodologia Lean, wywodząca się z Lean Management.

\footnotetext{
* dr Anna Bartoszewicz, Uniwersytet Warmińsko-Mazurski w Olsztynie, Wydział Nauk Ekonomicznych, Katedra Rachunkowości, e-mail: anna.bartoszewicz@uwm.edu.pl.
} 
Nowoczesne Zarządzanie Publiczne dotyczy również audytu wewnętrznego, który funkcjonuje od 2002 roku w wybranych jednostkach sektora finansów publicznych w Polsce ${ }^{1}$. Zauważa się, że wskutek podjętych przemian jego rola uległa znacznej modyfikacji, od narzędzia weryfikującego zgodność wykorzystania środków publicznych, do instrumentu badającego efektywność realizacji zadań i celów przez podmioty audytowane. Nowa koncepcja audytu wykształciła tak zwany audyt efektywnościowy, kwestionując leżącą u jego podstaw weryfikację procedur i metod. Zaakcentowała koniczność prowadzenia analizy przyczynowo-skutkowej, która pozwala na ocenę działalności jednostki pod kątem realizacji celów i prawidłowości wykonywania zadań. Ukierunkowanie prac audytowych na efektywność czyni audyt narzędziem unikatowym, które pozwala zmierzyć i ocenić skuteczność prowadzonej działalności. Przypisanie tak ważnej roli audytowi wewnętrznemu implikuje konieczność ciągłego doskonalenia tego procesu i skuteczne zarządzanie audytem wewnętrznym, który powinien współdziałać z metodą Lean Management. Wskazane staje się zatem wykorzystanie metodologii Lean, która w odniesieniu do audytu polega na niskokosztowym ukierunkowaniu działań na eliminowanie nieefektywnych etapów procesu audytu (marnotrawstwa), jego usprawnienie i zwiększenie wnoszonej wartości dodanej do podmiotu audytowanego.

Mając na uwadze ważność powyższych spostrzeżeń, cel główny artykułu sformułowano następująco: „Zaprezentowanie zasad funkcjonowania i wybranych narzędzi metodologii Lean Audit oraz wskazanie kluczowych obszarów podnoszenia efektywności procesu audytu wewnętrznego". W opracowaniu podjęto próbę odpowiedzi na pytanie badawcze - jak ponieść efektywność procesu audytu wewnętrznego wykorzystując metodologię Lean? Realizacja celu artykułu oraz odpowiedź na powyższe pytanie była możliwa dzięki analizie literatury przedmiotu badań oraz aktów prawnych. Zastosowano metodę obserwacji przebiegu procesu audytu w podmiotach publicznych. Wnioskowanie przeprowadzono metodą indukcji.

\section{Zadania audytora $w$ jednostkach sektora finansów publicznych a ocena efektywności dzialania komórki audytu wewnętrznego}

Audyt wewnętrzny w polskiej administracji publicznej funkcjonuje od 2002 roku, a jego początki oparte były głównie na realizacji wymogów postawionych przez Unię Europejską, która zobligowała Ministerstwo Finansów do wprowadzenia zmian w zakresie państwowej kontroli wewnętrznej. W praktyce zmieniono zapisy ustawowe ${ }^{2}$ i oparto wdrożenie audytu o benchmarking, wprowadzając rozwiązania, które sprawdziły się w innych krajach.

\footnotetext{
${ }^{1}$ Podmioty zobowiązane do prowadzenia audytu wewnętrznego wskazano w Ustawie z dnia 27 sierpnia 2009 r. o finansach publicznych.

${ }^{2}$ Zmiany pojawiły się w Ustawie z dnia 27 lipca 2001 r. o zmianie ustawy o finansach publicznych, ustawy o organizacji i trybie pracy Rady Ministrów oraz o zakresie działania ministrów, ustawy o działach administracji rządowej oraz ustawy o służbie cywilnej (Dz.U. nr 102, poz. 1116).
} 
W strukturach wybranych jednostek sektora finansów publicznych utworzono komórki audytu wewnętrznego oraz uregulowano sposób ich funkcjonowania.

Pierwotnie audyt wewnętrzny miał charakter narzędzia weryfikującego poprawność funkcjonowania obszaru finansowego w audytowanym podmiocie. W gestii audytora leżało zbadanie dowodów księgowych, zapisów w księgach rachunkowych, jak również sprawdzenie poprawności gromadzenia środków publicznych i dysponowania nimi.

Po raz pierwszy zakres działalności audytu zmieniła Ustawa z dnia 30 czerwca 2005 roku o finansach publicznych, która dostosowała audyt do międzynarodowych standardów. Zgodnie z jej treścią, audytorom przypisano obowiązek oceny zgodności funkcjonowania podmiotu z obowiązującymi przepisami prawa i wewnętrznymi procedurami jednostki. Rola audytora skupiała się głównie na badaniu gospodarności i efektywności podejmowanych działań w zakresie zarządzania i systemów kontroli. Miał on również możliwość podejmowania czynności doradczych w ramach prowadzonej działalności audytowej.

Od 1 stycznia 2010 roku powyższy zakres audytu został zmieniony (ustawa z dnia 27 sierpnia 2009 r.) i wprowadzono w struktury jednostek sektora finansów publicznych kontrolę zarządczą, której celem jest identyfikacja ryzyka na potrzeby efektywnej realizacji celów i zadań jednostki, a audytorom przypisano ocenę skuteczności jej działania.

Transformacja audytu, która dokonała się na przez kilkanaście ostatnich lat, ukierunkowała go na efekty. Można zatem przytaczać wiele argumentów potwierdzających lub negujących słuszność ich wprowadzenia. Nie ulega jednak wątpliwości, że nowa koncepcja wymusiła jednoczesną zmianę roli audytora wewnętrznego. Konsekwencją takich działań stała się weryfikacja funkcjonowania procesu audytu i działalności komórek audytowych, co w kontekście przedmiotowej tematyki znajduje swój wyraz w ich ocenie.

Mimo że od początku funkcjonowania audytu wewnętrznego w podmiotach publicznych działalność audytu była oceniana, dotyczyło to głównie zgodności podejmowanych działań z Międzynarodowymi Standardami Praktyki Zawodowej Audytu Wewnętrznego IIA i Kodeksem etyki audytora wewnętrznego ${ }^{3}$. Treść standardu atrybutu 1300 zobowiązuje bowiem zarządzającego audytem do przeprowadzania $\mathrm{w}$ ramach programu zapewnienia i poprawy jakości:

a) corocznej oceny wewnętrznej, obejmującej bieżące monitorowanie i samoocenę;

b) oceny zewnętrznej, która powinna odbywać się co najmniej raz na 5 lat i obejmować pełną ocenę zewnętrzną lub ocenę wewnętrzną z niezależną walidacją.

Departament Polityki Wydatkowej Ministerstwa Finansów w 2015 roku przeprowadził ponadto dodatkowo ocenę funkcjonowania audytu w 597 jednostkach administracji rządowej, dotyczącą następujących obszarów (Ocena funkcjonowania..., 2015):

- organizacji komórki audytu wewnętrznego,

- planowania i przeprowadzania audytu wewnętrznego,

\footnotetext{
${ }^{3} \mathrm{~W}$ odniesieniu do sektora finansów publicznych wymienione standardy został ogłoszone w formie Komunikatu Ministra Finansów i Rozwoju z dnia 16 grudnia 2016 r. w sprawie standardów audytu wewnętrznego dla jednostek sektora finansów publicznych (Dz. Urz. Min. Fin. z 2016, poz. 28).
} 
- efektywności audytu wewnętrznego,

- jakości audytu wewnętrznego.

Zgodnie z przyjętymi założeniami, organizację audytu oceniono z punktu widzenia przyjętych rozwiązań co do usytuowania komórki audytu w strukturze jednostki. Z kolei jego planowanie i przeprowadzanie zbadano pod kątem wykonania zadań zapewniających w stosunku do przyjętego planu audytu na dany rok. Efektywność zmierzono procentem przeznaczanego czasu bezpośrednio na audyt oraz wskaźnikiem akceptacji zaleceń, a opinię na temat jakości pracy audytu wydano na podstawie liczby przeprowadzonych ocen wewnętrznych i zewnętrznych zgodnie ze standardem 1300 IIA.

Należy zauważyć, że powyższe założenia zakładały weryfikację efektywności i jakości audytu wewnętrznego, jednak nie zweryfikowano samego procesu audytu (np. etapów, wykorzystanej metodologii, narzędzi). Powyższe stwierdzenia wynikają ze spostrzeżeń autorki, która od ponad 10 lat zajmuje się tematyką audytu wewnętrznego. W kontekście zmian w administracji państwowej wydaje się zasadne wkomponowanie w proces audytu innowacyjnych technik, które pozwoliłoby na jego doskonalenie. Niestety wciąż zauważa się, że w niektórych jednostkach audyt funkcjonuje jako rutynowe sprawdzanie zgodności z planem danego obszaru czy zjawiska, nierzadko ograniczając się jedynie do badania sfery finansowej (por. Moeller, 2011, s. 31). W takim układzie trudno nazwać proces audytu efektywnym. Zbadanie przebiegu poszczególnych jego etapów i wykorzystanej metodologii dałoby obraz efektywności wykonywanych zadań audytowych. Należy także podkreślić, że prowadzony proces audytu w administracji publicznej jest często zbyt rozległy, co rzutuje na jakość prowadzonych prac, powodując marnotrawstwo. W opinii autorki artykułu zasadna jest implementacja metodologii Lean Audit w celu podniesienia jakości działań audytowych, a następnie pomiar efektywności procesu audytu.

\section{Koncepcja ,szczupłego" procesu audytu}

„Szczupły proces audytu” z ang. Lean Audit odnosi się do stosowania zasad metodologii Lean w audycie wewnętrznym. Lean oparty jest na etapach pracy uznawanych za najbardziej efektywne i skuteczne, przy wykorzystaniu sposobów do osiągnięcia jak najlepszego celu lub efektu (Charter Institute of Internal Auditors, 2016).

Powyższy termin jest pochodną Lean enterprise system, czyli koncepcji szczupłego przedsiębiorstwa, która ma swoje źródło w Systemie Produkcyjnym Toyoty zapoczątkowanego w latach 40. XX wieku. Przedsiębiorstwo wdrożyło wtedy sposób określany jako produkcja na czas (Just in time), co stało się głównym czynnikiem przewagi konkurencyjnej (Bezdogan, 2010, s. 2).

Powyższa koncepcja została opisana w literaturze przez T. Ohno (1988), który zidentyfikował siedem typów marnotrawstwa w wykonywanych procesach, wymagających ograniczenia lub eliminacji. Dotyczyło to oszczędzania zasobów wykorzystywanych w procesie 
produkcji. Prace w przedmiotowej tematyce kontynuowali również Krafcik (1988) oraz Womack i Jones (1996).

Następstwem powyższych działań było wprowadzenie koncepcji szczupłego zarządzania Lean management, w którym przeniesiono opisywany kierunek myślenia na zarządzanie, a filozofia koncepcji oparta była na szczególnej wartości przypisywanej upraszczaniu, czyli zmniejszaniu liczby elementów składowych rozmaitych procesów i rezultatów działań organizacyjnych (por. Sobańska, 2013, s. 25). Ugruntowało to model zarządzania Lean nastawiony na eliminowanie marnotrawstwa i doskonalenie funkcjonujących procesów w danej organizacji.

Warto zauważyć, że techniki Lean były już stosowane z powodzeniem w różnych sektorach. Typowe korzyści z ich wykorzystania obejmują w kontekście redukcji takie elementy jak terminy, wady, koszty czy zapasy, zaś z punktu widzenia ulepszeń przynoszą zadowolenie klienta, wydajność, pojemność, szybkość reakcji czy też jakość ${ }^{4}$. Należy także podkreślić, że zasady Lean są szczególnie przydatne dla działów wykonujących zadania zapewniające, w której działalność wymaga ciągłego doskonalenia oraz zaspokojenia potrzeb klienta $\mathrm{w}$ jak najbardziej efektywny sposób. Takie czynności prowadzi, między innymi komórka audytu wewnętrznego, stąd zasadna jest implementacja założeń Lean w struktury audytu (por. Charter Institute of Internal Auditors, 2016).

Powyższe założenie jest również zgodne $\mathrm{z}$ definicją audytu wewnętrznego zawartą w Międzynarodowych Standardach Praktyki Zawodowej Audytu Wewnętrznego IIA, gdzie kładzie się nacisk ,na przysporzenie wartości i usprawnienie działalności operacyjnej organizacji”. Analiza procesu audytu zgodna z zasadami Lean wymaga w pierwszej kolejności ustalenia kim są klienci audytu i jakiego efektu oczekują, a następnie udzielenie odpowiedzi na następujące pytania:

1. Czy prowadzone audyty zapewniają maksymalną wartość dodaną dla audytowanej jednostki?

2. Czy przeprowadzane audyty są na tyle skuteczne, aby poprawić funkcjonowanie jednostki?

J.C. Paterson (2015, s. 7-8) wymienia pięć kluczowych zasad metodologii Lean:

1. Określenie wartości z punktu widzenia klienta.

2. Zidentyfikowanie strumienia wartości.

3. Stworzenie przepływu wartości.

4. Wdrożenie „dokładnie na czas”.

5. Dążenie do perfekcyjnego procesu.

Celem pierwszej zasady jest właściwe zdefiniowanie wartości dla klienta, czyli odpowiedź na pytanie - czego klient oczekuje po danym procesie? Znając odpowiedź na to pytanie należy uszczegółowić poszczególne jego sekwencje i opisać działania w danym obszarze, dzięki czemu zidentyfikowany zostanie strumień wartości. Ważna jest również

\footnotetext{
${ }^{4}$ https://www.efficientlearning.com/blog/cia/lean-auditing-part-one (8.06.2017).
} 
krytyczna ocena (z punktu widzenia klienta) każdego etapu procesu pod kątem wnoszenia wartości dodanej. Stworzenie przepływu wartości ma na celu znalezienie punktów marnotrawstwa, które może pojawić się w jakiejkolwiek formie (naprawy, opóźnienia, przerwy $\mathrm{w}$ dostawie). Ta zasada zobowiązuje również do zwrócenia szczególnej uwagi na działania przygotowawcze. Według czwartej zasady cel klienta jest realizowany dokładnie na czas, czyli ani zbyt wcześnie, ani też zbyt późno. Ostatnia z zasad obliguje do maksymalizacji wartości procesu bez zbędnych odpadów (marnotrawstwa). Ta zasada oparta jest na koncepcji „Kaizen”, która skłania do ciągłego doskonalenia procesu.

Zastosowanie powyższych reguł pozwala podnieść efektywność procesu audytu, zaś skuteczność metodologii Lean warunkowana jest przez odpowiednie wykorzystanie jej narzędzi i technik. Pozwalają one na wizualizację szczegółowych etapów procesu, dzięki czemu możliwa jest implementacja zmian, które pozwolą udoskonalić istniejący proces audytu. Przykładem narzędzi, które służą do tego celu jest mapowanie SIPOC oraz model 3M.

\section{SIPOC i model $3 \mathrm{M}$ jako narzędzia doskonalące proces audytu wewnętrznego}

Nazwa SIPOC pochodzi od pierwszych liter pięciu elementów procesu: Supplier (dostawców), Inputs (nakładów/wejść), Process (proces/przebieg), Outputs (efektów/wyjść) oraz Customers (klientów) ${ }^{5}$. Na ich podstawie buduje się diagram SIPOC, który może być dodatkowo rozbudowany o dwa kolejne elementy, tj. zasoby niezbędne do realizacji procesu czy też regulacje prawne, które odnoszą się do danego procesu ${ }^{6}$. Powyższe elementy zostaną przeniesione do rozważenia procesu audytu.

Schemat SIPOC jest narzędziem, które może być wykorzystane przez zespół komórki audytu do identyfikacji istotnych elementów doskonalenia procesu audytu jeszcze przed rozpoczęciem jego realizacji. Przeprowadza się to zgodnie z określonymi kryteriami. W efekcie audytorzy otrzymują podpowiedź o wpływie i zaangażowaniu poszczególnych składowych procesu w jego doskonalenie. Modelowe ujęcie elementów SIPOC w odniesieniu do procesu audytu wewnętrznego zilustrowano na rysunku 1.

Przedstawiony proces mapowania ukazuje wiele pozycji w ramach pięciu zdefiniowanych elementów (SIPOC), co ułatwia odtworzenie przebiegu procesu, jak również stworzenie możliwych scenariuszy. Implementacja tego narzędzia w struktury audytu w skuteczny sposób wskaże wiele możliwości poprawy planowania audytu, wykonywania zadań audytowych czy sprawozdawczości (Paterson 2015, s. 15).

\footnotetext{
${ }^{5} \mathrm{https}: / /$ www.governica.com/SIPOC (8.06.2017).

${ }^{6} \mathrm{http}$ //it-consulting.pl/autoinstalator/wordpress/2011/06/07/raci-sipoc-i-inne-czyli-modelowanie-organizacjic-d (10.06.2017).
} 


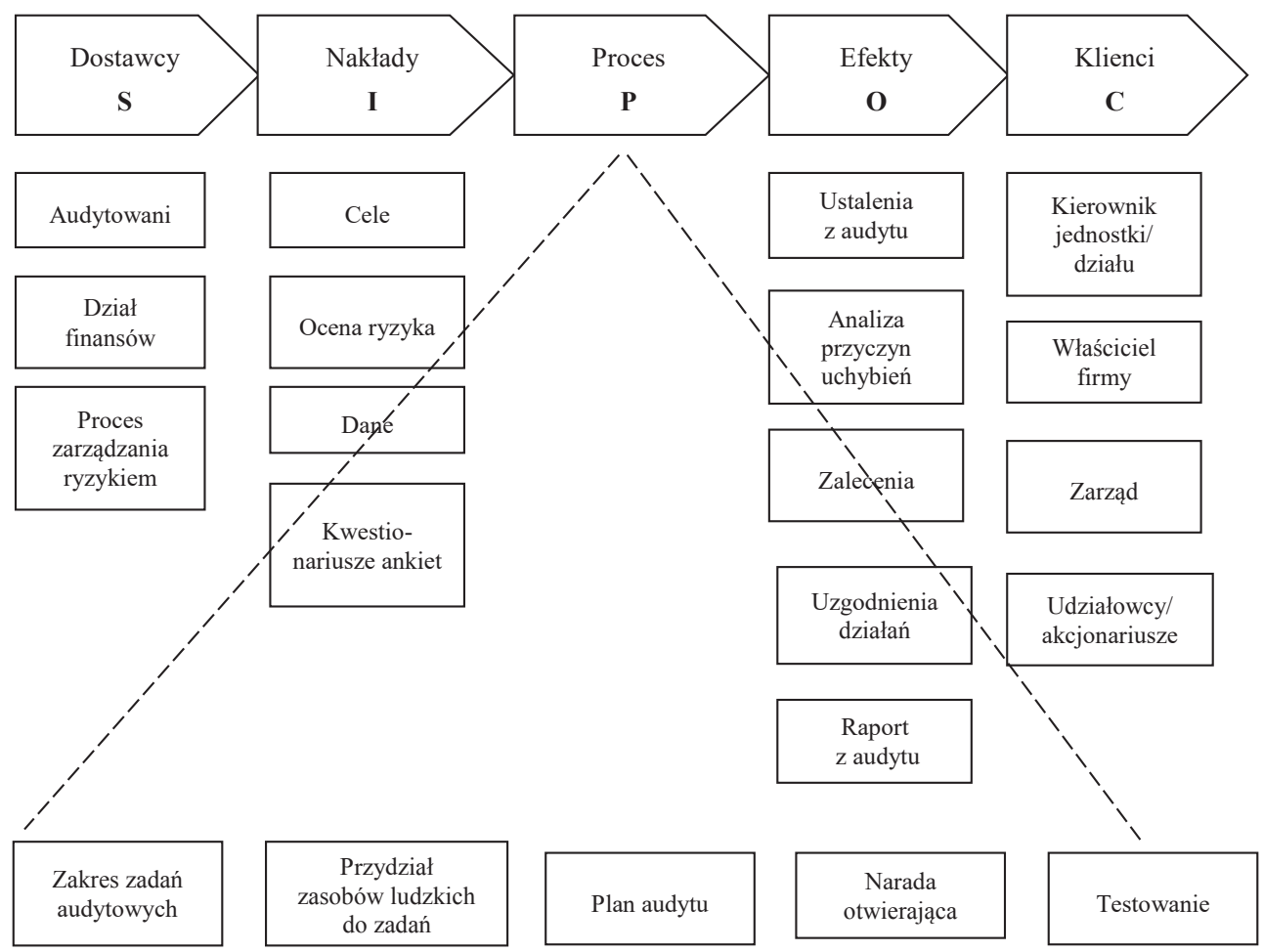

Rysunek 1. Przykładowy model mapowania SIPOC dla procesu audytu wewnętrznego

Źródło: opracowanie własne na podstawie Peterson (2016).

SIPOC jest narzędziem szczególnie użytecznym, jeśli nie jest jasne?:

- kto dostarcza nakłady do procesu,

- jaka specyfikacja umieszczona jest na wejściu do procesu,

- kto jest właściwie odbiorcą rezultatu z procesu,

- jakie są wymagania klientów.

Poza możliwością zastosowania diagramu SIPOC w doskonaleniu procesu audytu wewnętrznego możliwe jest również wykorzystanie modelu 3M Toyoty w przedmiotowym zakresie. Model ten zbudowany jest z trzech elementów wzajemnie na siebie oddziałujących: eliminowania marnotrawstwa (jap. Muda), zmienności (jap. Mura) oraz przeciążenia (jap. Muri). W kontekście wykorzystania powyższego modelu w audycie wewnętrznym najważniejszy jest element $M u d a$, który pozwala na identyfikację przy użyciu zwykłej obserwacji zbędnych punktów w wykonywanym procesie, które nie przynoszą wartości dodanej. Może to dotyczyć zbyt wielu osób zaangażowanych w zadania audytowe, nadmiernego czasu

\footnotetext{
${ }^{7}$ https://www.isixsigma.com/tools-templates/sipoc-copis/sipoc-diagram (8.06.2017).
} 
przeznaczanego na określone zadanie zapewniające czy też doradcze, nieefektywnego wydatkowania zasobów finansowych przeznaczanych, np. na rzeczoznawców, błędnej organizacji stanowisk i etapów audytu. Z kolei obszar Mura dotyczy nieregularności w wykonywanych działaniach, co w odniesieniu do procesu audytu może przejawiać się zmiennością w stosowaniu lub niestosowaniu standardów czy też zasad ujętych w karcie audytu. Muri, czyli nadmierne przeciążenie, może być efektem nieprzewidzianej nieobecności pracowników (zarówno audytorów, jak i audytowanych) lub też zbyt dużej liczby zadań zapewniających ujętych w rocznym planie audytu.

Dla szczegółowej analizy zidentyfikowanych problemów w procesie audytu należałoby przeprowadzić badanie pogłębione w dwóch ujęciach. Pierwsze ujęcie dotyczyłoby weryfikacji i obrania kierunków działań w odniesieniu do znanych problemów, drugie byłoby weryfikacją i opracowaniem działań na przyszłość w odniesieniu do przypuszczalnych nieprawidłowości, które mogą się pojawić (zob. szerzej Paterson, 2016).

\section{Uwagi końcowe}

„Nowoczesny” proces audytu wewnętrznego w administracji publicznej powinien być efektywny i skuteczny oraz wnosić do organizacji jak najwyższą wartość dodaną. Prowadzone rozważania w niniejszym artykule są jedynie zarysem koncepcji Lean, która może być prowadzona w celu doskonalenia procesu audytu. Wymaga ona jednak uszczegółowienia i szerszego ujęcia dla praktycznego jej zastosowania. Należy jednak podkreślić, że pomimo wielu zalet metodologii Lean zwykle nie jest ona wykorzystywana w polskiej administracji publicznej. Przyczyną tego stanu rzeczy może być opór zarządzających audytem przed wdrożeniem innowacyjnych rozwiązań, deficyt czasu i osób w działach audytu lub też brak znajomości specyfiki metodologii Lean.

\section{Literatura}

Bezdogan, K. (2010). Evolution of the Lean Enterprise System: A crucial Synthesis and Agenda for the Future. Working Paper, Center for Technology, Policy and Industrial Development, Massachusetts Institute of Technology, Cambridge, MA.

Czarnecki, J.S., Sikorski, C. (2013). Lean management. W: I. Sobańska (red.), Lean accounting. Integralny element lean management. Szczupła rachunkowość w zarządzaniu (s. 11-32). Warszawa: Wolters Kluwer.

http://it-consulting.pl/autoinstalator/wordpress/2011/06/07/raci-sipoc-i-inne-czyli-modelowanie-organizacji-c-d/ (10.06.2017).

https://www.efficientlearning.com/blog/cia/lean-auditing-part-one (8.06.2017).

https://www.governica.com/SIPOC (8.06.2017).

https://www.isixsigma.com/tools-templates/sipoc-copis/sipoc-diagram (8.06.2017).

Komunikat Ministra Finansów i Rozwoju z dnia 16 grudnia 2016 w sprawie standardów audytu wewnętrznego dla jednostek sektora finansów publicznych (t.j. Dz. Urz. Min. Fin. z 2016, poz. 28).

Międzynarodowe Standardy Praktyki Zawodowej Audytu Wewnętrznego (2012). Tłum. IIA-Polska, Warszawa.

Moeller, R. (2011). Nowoczesny audyt wewnętrzny. Warszawa: Wolters Kluwer.

Ocena funkcjonowania audytu wewnętrznego w jednostkach sektora finansów publicznych w roku 2015 (2016), Warszawa: Departament Polityki Wydatkowej Ministerstwa Finansów. 
Ochno, T. (1988). Toyota Production System: Beyond Large-Scale Production. Productivity Press, Portland, OR. Paterson, J.C. (2016). Lean Auditing-An introduction. New York: Materials from International Conference IIA, July $17-20,2016$.

Paterson, J.P. (2015). Lean Auditing. Driving Added Value and Efficiency in Internal Audit. Great Britain: Wiley.

Ustawa z dnia 27 lipca 2001 roku o zmianie ustawy o finansach publicznych, ustawy o organizacji i trybie pracy

Rady Ministrów oraz o zakresie działania ministrów, ustawy o działach administracji rządowej oraz ustawy o służbie cywilne (t.j. Dz.U. nr 102, poz. 1116).

Ustawa z dnia 27 sierpnia 2009 r. o finansach publicznych (t.j. Dz.U. 2016, poz. 1870 z późn. zm.).

Ustawa z dnia 30 czerwca 2005 r. o finansach publicznych (t.j. Dz.U. nr 249, poz. 2104).

Womack, J.P., Jones, D.T. (1996). Lean Thinking: Banish Waste and Create Wealth in Your Corporation, Simon \& Schuster, New York.

\title{
SELECTED ASPECTS OF THE IMPLEMENTATION OF THE LEAN METHODOLOGY IN THE CONTEXT OF INCREASING THE EFFICIENCY OF THE INTERNAL AUDIT PROCESS IN THE PUBLIC ADMINISTRATION
}

\begin{abstract}
Purpose - The aim of the article is to present the principles and selected tools of Lean Audit methodology as well as shows the key areas for increasing the efficiency of the audit process.

Design/methodology/approach - The methods used to attain the objective included the analysis of literature and legislation concerning the subject. The method of observation was used in the scope of audit process in public entities. Inference was based on induction method.

Findings - The article presents the concept of Lean Audit methodology. There was indicated the possibility of using its tools - SIPOC and MURA model for improving the audit process in the public administration. Originality/value - The Lean Audit methodology in Polish public administration, which was presented in this article it has not been widely discussed so far in publications by other authors. Due to transformation of internal audit in Polish public administration the importance of this issue should be emphasized.
\end{abstract}

Keywords: audit, internal audit, Lean Audit, efficiency, SIPOC

\section{Cytowanie}

Bartoszewicz, A. (2017). Wybrane aspekty implementacji metodologii Lean w kontekście podniesienia efektywności procesu audytu wewnętrznego w administracji publicznej. Finanse, Rynki Finansowe, Ubezpieczenia, 3 (87/1), s. 67-75. DOI: 10.18276/frfu.2017.87/1-06. 